JEL Classification: E 27; F 43; M 13

UDC 330.341 .1

DOI: $10.30857 / 2415-3206.2019 .2 .11$

\section{WORLD EXPERIENCE OF FRANCHISING RELATIONS}

\section{N. KULAK 1}

${ }^{1}$ Kyiv National University of Technologies and Design, Ukraine

Introduction and purpose of the methods of unity of analysis and study. The domestic business market synthesis, system-structural methods, requires effective development methods of generalization and measures. Increasing the investment prediction, methods of interrelation of attractiveness of domestic enterprises theoretical and practical aspects of depends more on the favorable legal research.

climate of the country and the timing of return on investment. Franchising plays the role of an effective tool to accelerate business development and expansion and at the same time ensure a rapid return to investors on their investments. Important for creating the conditions necessary for the development of domestic entrepreneurship is the introduction of measures that would enhance the use of franchising. Leveraging the experience of franchising countries should help Ukrainian businesses gain constructive guidance on using franchising as a tool to start, expand, and improve their business.

The hypothesis of scientific research basically contains a system of scientific provisions and principles of business development, which substantiate the availability of effective tools that can create the necessary conditions for improving the investment climate of the country and increase the productivity of business activity.

Results: Based on the generalization of the analysis of economic indicators of the investment attractiveness of the markets of the leading countries of the world and Ukraine due to the use of franchising in business activity, the presence in Ukraine of promising franchising sectors of the national economy has been proved. Recommendations have been developed on the strategy of actions aimed at creating a favorable climate for franchising.

Conclusions: Franchising is a business model based on business partnerships, which provides entrepreneurs with the opportunity to start, develop and expand business through the resources of partners. The analysis of economic indicators of the effectiveness of the investment attractiveness of the markets of franchising countries shows the positive experience and the existing potential of using the franchising for the development of the economy of Ukraine.

Research methods: general methods of scientific knowledge, such as

Keywords: franchising; investments; business; business. 


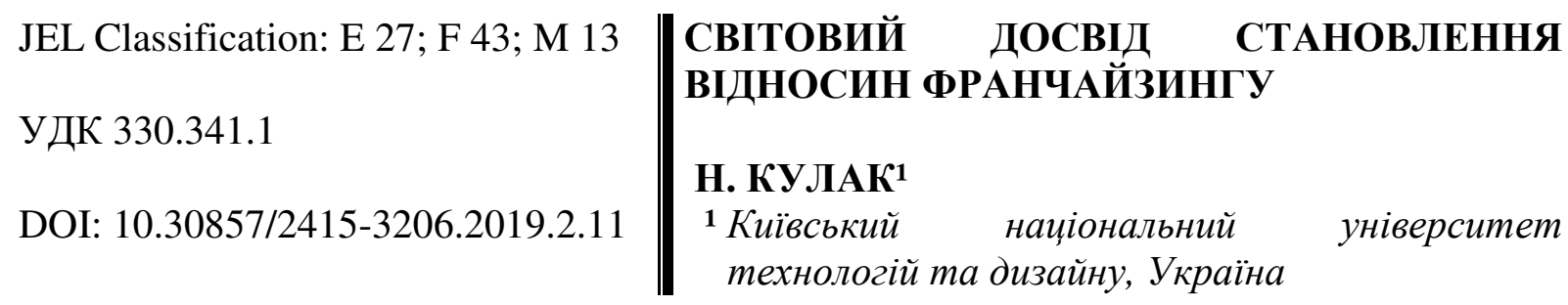

Вступ i мета дослідження. Вітчизняний ринок підприємницької діяльності потребує застосування дієвих заходів розвитку. Підвищення інвестиційної привабливості вітчизняних підприємств залежить в більшій мірі від сприятливого правового клімату країни та від термінів окупності капіталовкладень. Франчайзинг відіграє роль ефективного інструменту прискорення розвитку i розширення бізнесу та одночасно забезпечує швидке повернення інвесторам їх капіталовкладень. Важливим для створення умов необхідних для розвитку вітчизняного підприємництва $є$ впровадження заходів які б сприяли активізації використання франчайзингу. Використання досвіду країн, що активно застосовують франчайзинг має допомогти українському бізнесу отримати конструктивні рекомендації щодо використання франчайзингу в якості інструменту для започаткування, розширення та удосконалення підприємницької діяльності.

Гіпотеза наукового дослідження в своїй основі містить систему наукових положень і принципів розвитку підприємницької діяльності, які обгрунтовують наявність дієвих інструментів, що спроможні створити необхідні умови для покращення інвестиційного клімату країни та підвищити результативність підприємницької діяльності.

Методи дослідження: загальні методи наукового пізнання, такі як методи єдності аналізу і синтезу, системноструктурні методи, методи узагальнення та прогнозування, методи взаємозв'язку теоретичних i практичних аспектів дослідження

Результати: на основі узагальнення аналізу економічних показників результативності зростання інвестиційної привабливості ринків провідних країн світу та України завдяки застосуванню у підприємницькій діяльності франчайзингу доведено наявність в Україні перспективних для застосування франчайзингу галузей народного господарства. Розроблено рекомендації щодо стратегії дій, спрямованих формування сприятливого клімату для впровадження франчайзингу.

Висновки: франчайзинг виступає моделлю упорядкування бізнесу, побудованого на засадах ділового партнерства, яке забезпечує підприємцям можливість започатковувати, розвивати та розширювати підприємницьку діяльність за рахунок ресурсів партнерів. Аналіз економічних показників результативності зростання інвестиційної привабливості ринків країн, які застосовують франчайзинг свідчить про позитивний досвід та наявний потенціал використання франчайзингу для розвитку економіки України.

Ключові слова: франчайзинг, інвестиції, підприємницька діяльність, бізнес. 
Setting the problem. In order to consider the global experience of franchising and the national peculiarities of franchising in some countries of the world, it is necessary to focus on the emergence of a franchising institution.

There are several versions regarding the origin of the franchising institute. For example, some scholars believe that the birth of franchising began in medieval France, where the concept of "franchise" understood the special privilege or "freedom" that was given to the French kings by their vassals. It could be the right to hunt in royal forests or the exclusive right to trade in some goods, the right to hold markets and fairs, the right to keep a ferry, to build roads and breweries [9]. Other scholars believe that franchising originated in the XVIII century. in England, where the king allowed the nobility to collect taxes in certain territories, and as a reward - to leave to himself some of the collected. In the Oxford English Dictionary, the term "franchising" means all the rights and freedoms of bishops granted by the royal crown in 1559, and "franchises" means trade fairs, markets and other places [6]. Free people or citizens of cities were given the right to sell their goods in the city, at markets and at fairs. In its most typical form, franchising appeared in the British system of "connected houses" used by brewers to maintain the necessary sales volume. In exchange for a loan or lease of property, the brewer received a permanent yard as a market for his beer. The conventional date for the use of the term "franchising" is considered to be 1840 [9].

Analysis of the latest research and the unresolved part of the problem. Economic and legal problems of franchising relations, regulation of franchises, peculiarities of signing a franchise agreement, determining the place and role of franchising in the development of the Ukrainian economy, analysis of the development of franchising relations in Ukraine, which is the subject of this study, were reflected in the works of such domestic and foreign specialists: M. Bedrynts, Z. Varnalii, O. Vasiliev, A. Voychak, V. Gerasimchuk, O. Gorodov, A. Grischenko, A. Gekht, V. Denysyuk, V. Dovgan, A. Dovgert, J. Deltey, V. Evdokimova, D. Zemlyakova, I. Carpetnik, G. Kochetkov, O. Korolchuk, O. Kuzmina, O. Legeidi, M. Mendelssohn, Y. Murray, A. Pavlenko, I. Rykov, R. Ruotzi, Y. Sidorov, S. Skibinsky, S. Sosny, D. Stenworth, A. Starostina, V. Terekhov, N. Tereshchuk, G. Cirat and others. In recent years, the range of researchers in franchising has expanded significantly, especially in the context of innovative economic development. It is possible to name the works of such specialists as A. Baghdasaryan, S. Burley, V. Kolesnikov, A. Orlov, M. Rosenberg, V. Solovyov, S. Spinelli, F. Filin and others. Despite the considerable contribution of the aforementioned scholars to the development of franchising topics, many issues still remain poorly understood. 
The purpose of the article is identification of economic preconditions and research of development and application of organizational methods of introduction of new technologies based on franchising.

Explanation of the main research material. In the United States, franchising was the first to be used by Singer, which began mass production of sewing machines and began to charge retailers of Singer products for the exclusive right that they were granted to sell products and provide customer service in the designated area. Such franchise agreements were, in their content, distributor agreements with additional obligations of the franchisee (dealer) to provide on-demand machine maintenance [8].

In 1898, a similar system was developed by General Motors, which began to attract independent dealerships to sell their cars. Gradually franchising began to be used in retail. The largest distribution of goods through franchise networks was in the refrigeration industry. Thus, franchising has been actively used and continues to be used by such world-renowned companies as Coca-Cola, Pepsi, $7 \mathrm{Up}$ and others.

McDonald's is the most visible and compelling example of becoming and developing a franchise business model. A characteristic feature of McDonald's in Ukraine is that it develops on a corporate basis, not on a franchise basis.

According to the statistics of the USA, with the expiration of 5 years of activity in the market $23 \%$ of private enterprises are retained, and with the expiration of 10 years $-18 \%$. At the same time, franchising companies closed in 8 years only 8 out of 100 , and in 10 years -10 out of 100 . Many US companies sold their franchises to other countries, which contributed to the fact that American franchising, having a solid internal experience, began to move to markets of other countries. Franchising gradually began to develop in the CIS and Baltic countries. Today, there are approximately 18,500 franchisees and over 2 million franchisees worldwide. Currently, franchising is used in almost all areas of business. The International Franchising Association identifies 70 industries in which franchising techniques can be used.

The leaders in franchising and exporting franchisees around the world are the United States, Canada, Australia, Japan, Korea, Germany, France and the United Kingdom.

In China, franchising emerged in the early 1990s, and by early 2004, China was ranked second after the United States in terms of franchise development. Today, China is not only the world leader in terms of attracted foreign investment, but also quite confidently ranks fourth among the largest economies in the world: the US, Japan and Germany. China is the world leader in the number of franchise systems.

According to the latest data, there are currently 280,000 franchisees in China, with 4 million employees in the franchise sector. The peculiarity of the 
Chinese franchise is that it is mainly represented by foreign brands: American, European and Asian. The most widespread in the Chinese franchise market have been American networks. These are KFC and over 200 points, McDonald's about 1000 points, Pizza Hut, Starbucks and more. The leader of franchise networks is the Kodak brand, which operates in China under the brand name KEX photoexpress and integrates more than 9,200 photo salons into its network. Equally well known in China is a franchise network such as the Subway Sandwich Shop, which first opened in Beijing in 1995. The most striking representatives of the franchise chains are Chinese cuisine restaurants: the Malan restaurant chain, which now has more than 500 restaurants worldwide, which is a combination of famous Chinese noodles and modern fast food; known since the nineteenth century, the franchise of the Beijing restaurant "Quan Ju De's", which has a franchise network of more than 60 restaurants.

In recent years, there has been an increasing influence of China on world fashion. Almost all the world-famous fashion brands are represented in China, where their serial production also takes place. In Asia, such as Japan today, there are 1,100 franchisors and 200,000 franchisees, in Korea - 1,300 franchisors and 100,000 franchisees.

In the United States, which is considered the leader in the development of franchise relations, today there are 3,000 franchisees and 800,000 franchisees. Annual sales within the franchise system exceed EUR 5 trillion, with around $40 \%$ of retail businesses being franchised. The most active franchising systems in the US are America Center (services), Athlete's Foot (sports equipment), Avis (car rental), Mc Donald's (fast food), Burger King (fast food network), "Baskin Robbins" (ice cream), "Domino's Pizza" (pizza delivery), "Century 21" (real estate), "ERA" (real estate), "City Looks" (beauty salons), "Future Kids" (educational services), Quality Hotel, and more.

Today, there are 1,200 franchisors and 300,000 franchisees in Canada.

With regard to the development of franchising in Germany, Poland and the Czech Republic, in terms of number of franchisors and franchisees, Germany occupies one of the leading positions among European countries. According to official data, there are currently 1,300 franchisors and over 55,000 franchisees. Of the 1,300 registered franchises, $90 \%$ are German and 10\% are foreign. The franchise turnover is $€ 22.4$ billion.

The fastest growing German franchise has seen the fastest growth in fast food and service, car dealerships and car services, education, tourism, hotel business and the entertainment industry. Despite Poland's borders with Germany, franchising has not gained such distribution: only $10 \%$ of the market operates under a franchise system. The Czech Republic, unlike Poland, is more profitable to use the neighborhood with Germany. About 30\% of German imports go to the Czech Republic, and 35\% - exports to Germany. 
France is also considered one of the leaders in the development of franchising. Today there are 720 franchisees and 33,300 franchisees. According to the French Franchise Federation, the largest turnover of franchising is observed in real estate. Food and clothing also account for a significant proportion of franchising.

The UK is characterized by a very small gap in the development of franchising. Currently, there are only about 670 franchisors. The extent of the use of the franchise model of business expansion in the UK is the fast food industry.

Italy, as well as Germany, France and the United Kingdom, took the leading position in the development of franchising. In Italy, franchising as a way to expand business has been known since 1970 and has 760 brands, the number of franchisees is 48500. The successful development of franchising in Italy is facilitated by the fact that each new franchisee receives from the Italian Association 50,000 euros, of which 25,000 - a grant and the other 25,000 - a loan of a small percentage. Franchising in Spain is also developing quite actively. There are currently 646 franchisors and 27,000 franchisees. About 82,000 employees are employed in the franchise business sector. Annual turnover in the franchise system is 3.5 billion euros.

There are 350 franchisors and 15,000 franchisees in Sweden today. There are 320 franchisors and 4,500 franchisees in Austria. In Denmark there are 100 franchisors and over 2000 franchisees.

In Ukraine, the franchise system is developing such retail chains as: "Pizza Celentano", "Vienna Buns", "Fornetti", "Coffee Life", "Nasha Ryaba", "Chain of Stores", "TEZ Tour", "Universal" Cleaner, UN Moment, IDS Aqua Service, Fit Curves, Sportlife, Helen Doron, Express Manicure, Our Edge, Avanti, New York-Street Pizza , "Mexx", "MANGO", "COLUMBIA", "Arber", "Nike", "Atlantic", "Bosch Service", "Liqui Moly", "Vianor", "Savage", "Romstal Ukraine", "Eldorado " and many others.

In 2011-2012, the franchising market of both Ukraine and the CIS was generally characterized by a high level of interest of foreign investors in winning the Ukrainian market and developing cooperation with Ukrainian partners. Despite the fact that in 2008-2011, the number of franchisees decreased by 40$50 \%$, the state of the franchise market experienced a qualitative improvement, since the reduction was due to those franchises that did not meet the requirements for this kind of relationships. The most profitable and active companies in 2011-2012 were developing foreign franchises.

In 2012, thanks to the Euro 2012 Championship in Ukraine, the most active investment was observed in the field of hotel business, which opened up opportunities for joining the worldwide hotel chains. In the healthcare system, both in Ukraine and worldwide, franchising is virtually undeveloped, with the 
exception of dental services, pharmacies and opticians. Although medical franchising is a new area of business development for Ukraine, companies such as Zablotsky Clinic, Back Pain Clinic, Ophthalmic Clinic Novy Zyr, Invitro Laboratory operate on a franchise basis, Dr. Bubnovsky Medical Center, Close People Medical Company and some others.

Pharmacy franchising is gaining popularity in Ukraine, the success of which is due to the fact that pharmacies are essential commodities that are always in demand by consumers. The most striking examples of pharmacies operating on a franchise basis are "Good Day Pharmacy", "There is a Pharmacy", "Alpha Farm", "Evalar".

Today, franchising agreements are also being extended in the field of educational services. In particular, some foreign language schools operate under the franchise system. For example, the international English language school "Mortimer English Club", which was first introduced in the market for educational services in Germany, has been working well with the franchise concept since 1999, incl. and in Ukraine. The Language Language School provides a range of foreign language learning services for children and adults.

Interesting for the Ukrainian market is the activity of the company "ED.UA", which started operating in 2010. The product of this company enables parents to get information about their children's performance and to follow the learning process. ED.UA franchise is a special electronic system for accounting of grades, remarks and homeworks of students of schools, lyceums and institutes. That is, "ED.UA" has essentially created a new standard of learning, through which innovative technologies are introduced into the learning process.

A brand new sales concept was launched with the brand name "31 Century" - a store of high-tech franchises. The range of sales is technological innovations. The specificity of the company is that it sells technological innovations that are only ahead of their time. The products of this brand are not only unique, they are also very practical.

Also noteworthy is the franchise of ABBYY, one of the world's leading developers of optical document recognition technologies and linguistic software.

The analysis of the Ukrainian franchise market shows that franchise offers in Ukraine are becoming more diverse every day, new industries and new technologies are emerging. According to experts of the Federation of Franchising Development (FDF) [7], there is a high prospect of sectoral business development, which in the future will work under the conditions of franchising.

The Franchise Development Federation identifies 29 sectors of the Ukrainian economy that have prospects for their own development and involvement of foreign franchises. Investment-attractive industries for franchising, and therefore needing state support, are the mining and chemical industries, agriculture, real estate, automotive, power generation, manufacturing 
of electronic and optical equipment, healthcare, and laboratory research services. and security services.

Recently, the gradual development of franchise relations in the market of high-tech goods and services (software, computer industry, multimedia, Internet services, mobile communications) has begun to follow. An innovative tool, such as eco-franchising, has appeared on the Ukrainian market, the essence of which is to sell eco-labeled goods. It should be noted that, despite the diversity of franchising relationships, the most interesting from the point of view of investment and innovation attractiveness are those franchises that are associated with the implementation of technology in the production processes of national entities and those that have the potential to contain technology.

Given the current state of development of franchising relations in Ukraine, and given the emergence of new industries that actively use the technology of franchising business development, it is necessary to emphasize the need not only for clear legislative regulation of franchising relations, but also for the direction of legal policy in the field of franchising relations with specialization of franchising systems. A separate line of franchising legislation should be the consolidation of such forms of franchising that are associated with the implementation of technology in the production processes of business entities.

Despite the rapid development of franchising in Ukraine, it will be incorrect to say that in our country proper conditions are created for the development of franchising business. Legislative regulation of franchising relations, or according to national law - commercial concession is carried out by the Civil and Economic Codes of Ukraine, but is at a primitive level. There is no specific legal act regulating franchising relations in Ukraine. Some domestic scholars are of the opinion that since the franchise agreement is governed by general contract law, it is inappropriate to form specific legislation in the field of franchising.

However, there is a different view as to whether franchising requires special legal regulation. Some practitioners believe that the adoption of a detailed and balanced, in terms of reciprocity obligations of the parties to the franchise agreements, a legal act is a prerequisite for the development of commercial concession relations in Ukraine, because such a rather complex type of relationship does not have a critical mass of relevant practice, especially, taking into account issues of intellectual property relations. In this context, an important aspect is not only the adoption of a specific franchise law that details both the content of the contract as a whole and clearly defines its subject matter and other essential conditions, but also defines at the legislative level the criteria that would allow considering a commercial concession agreement as a form of innovative investment. 
In addition to the lack of a proper legal framework in the field of regulating commercial concession relations, there are such groups of factors that impede the rapid development of franchising in Ukraine [1;2;3]: economic: instability and unpredictability of Ukrainian economy development; the lack of the necessary entrepreneurs (potential franchisees) with the necessary start-up capital for entering the franchise system and difficulties in obtaining loans; organizational and legal: lack of adequate infrastructure for servicing franchisees; imperfection of legal support of franchising relations in Ukraine; socio-psychological: lack of proper experience of using franchising form of cooperation among domestic entrepreneurs; the lack of due respect for the intellectual property of other market players in a large part of domestic entrepreneurs, as well as the willingness to strictly adhere to the standards and criteria set by the franchisor; insufficient number of domestic qualified specialists in the field of franchising; a high degree of distrust in the franchising form of business organization due to the lack of popularization of franchising in Ukrainian business practice, etc.

Solving the above problems will help to expand the use of franchising form of business activity in Ukraine and, as a consequence, to solve a number of problems of domestic business development.

\section{References}

1. Vynohradska, A. (2004). Komertsiine pidpryiemnytstvo: suchasnyi stan, stratehii rozvytku: monohrafiia [Commercial entrepreneurship: current status, development strategies: monograph]. Kyiv: Tsentr navch. lit. 807 p. [in Ukrainian].

2. Denisenkov, V. (2004). Proshchai, teoriia... [Goodbye theory...]. Biznes [Business], No. 9, P. 98-99.

3. Kabakova, E. (2004). Osobennosti finansirovaniia franchaizinga [Features of financing franchising]. Finansovaia konsultatciia [Financial consultation], No. 23/24, P. 4-24 [in Russian].

4. Oxford English Dictionary, 1933. P. 1630.

5. International Franchise Association. Retrieved from: http://www.franchise.org.

6. European Franchise Federation. Retrieved from: http://www.eff-franchise.com.

7. Innovation in Franchising Some illustrations from the French franchising chains. Retrieved from: http://www.escpeurope.eu/conferences/ marketing/2008_cp /Materiali/Paper/Fr/Perrigot_

\section{Література}

1. Виноградська А. Комерційне підприємництво: сучасний стан, стратегії розвитку: монографія / А. Виноградська. - Київ: Центр навч. літ., 2004. - 807 с.

2. Денисенков В. Прощай, теория... /

В. Денисенков // Бизнес. - 2004. - № 9. - C. 98-99.

3. Кабакова Е. Особенности финансирования франчайзинга / Е. Кабакова // Финансовая консультация. - 2004.№ 23/24 . - C. 4-24.

4. Oxford English Dictionary, 1933. C. 1630 .

5. International Franchise Association [Електронний pecypc]. - Режим доступу: http://www.franchise.org.

6. European Franchise Federation. Retrieved from: http://www.efffranchise.com.

7. Innovation in Franchising Some illustrations from the French franchising chains. - Retrieved from: http://www. escpeurope.eu/conferences/marketing/20 
Martinez.pdf.

8. Sosna, S.A., Vasileva, E.N. (2005). Kommercheskaia kontcessiia [Commercial concession]. Moscow: Akademkniga. 375 p. [in Russian].

9. Franchising \& Licensing - What are they? and how can you benefit from them? Retrieved from: http://www.wipo.int/export/sites/www/sme/en/doc uments/pdf/franchising.pdf.

10. International Classification of Goods and Services for the Purposes of the Registration of Marks / Worlad Intellectual Property Organization. Tenth Edition. Part II. 170 p. Retrieved from: http://www.wipo.int/export/sites/ www/classifications/nice/en/pdf/text_ncl_10_part _2.pdf. 08_cp /Materiali/Paper/Fr/Perrigot_Marti nez.pdf.

8. Сосна С. А. Коммерческая концессия / С. А. Сосна, Е. Н. Васильева. - М.: Академкнига, 2005. - 375 c.

9. Franchising \& Licensing - What are they? and how can you benefit from them? - Retrieved from: http://www.wipo.int/export/sites/www/s me/en/documents/pdf/franchising.pdf. 10. International Classification of Goods and Services for the Purposes of the Registration of Marks [Electronic resource] / Worlad Intellectual Property Organization. - Tenth Edition. Part II. 170 p. - Retrieved from: http://www. wipo.int/export/sites/www/classifications /nice/en/pdf/text_ncl_10_part_2.pdf. 